\title{
Civilizations: Challenges and Answers of The Modern World
}

\author{
Zagidullin M. I. \\ Almetyevsk branch of University of Management "TISBI", \\ Almetyevsk, Russia
}

\author{
Stenyashina N. L. \\ Almetyevsk branch of University of Management "TISBI", \\ Almetyevsk, Russia \\ nadingod13@mail.ru
}

\author{
Nazmutdinova R. N. \\ Almetyevsk branch of University of Management "TISBI", \\ Almetyevsk, Russia
}

\begin{abstract}
The article presents the analysis of one of the main components of modern society and state - civilization. According to the research on modern civilizations, the chronological framework of which falls on the XX-XXI centuries, this article considers the changes that have become epochal. The authors studied the scientific works of native and foreign scientists in the sphere of history, political science, cultural studies and sociology. The authors focus on the emergence of various challenges faced by modern civilization. They underline the need to study the civilizational processes that are a multifaceted phenomenon and have a significant impact on world history, world politics, world culture.
\end{abstract}

Keywords-civilizations; civilizational processes; cultures; technologies; communications; globalization.

\section{INTRODUCTION}

Under civilization it is necessary to understand a set of economic, social, political, spiritual phenomena observed in society. In the center of the study - the person and his interests as a system-forming principle in the study of modern society and the state.

Interpretation of the civilization concept may be different. Under civilization can be understood, for example, Earth civilization, the civilizations of the West and the East. The concept of civilization may include North American civilization represented by the United States, Chinese civilization. Special civilization should be characterized Russia.

The approach proposed by the authors of the article allows to study different States in the world community as modern civilizations on a more substantial level than the use of the traditional approach. This is important in a globalizing world, deep and multifaceted transformations that permeate all spheres of the international community life. Accordingly, the world economic relations, institutions of power and management, social policy and culture are affected. The civilizational processes taking place in the modern world are of greatest interest. This interest is due to the fact that in the world with the participation of various factors, serious changes have occurred and are taking place, affecting not only individual States, but also our planet as a whole.

The meanings, content and consequences of such changes require close attention and the most serious analysis. The aim of this research authors is to show the relationship, mutual influence of various past events related to the present and the predicted of the future. This, in our opinion, is the relevance of the work

\section{LITERATURE REVIEW}

The questions of the civilizations development are raised in the scientific works and speeches of the famous statesmen and politicians. In his famous speech at the 2007 Munich conference, Russian President Vladimir Putin clearly defined that the world is turning from a unipolar world into a multipolar world. This approach allowed, taking into account the global players in the international arena, to represent modern world politics at a new level, including the development of modern civilizations [11]. Barack Obama in his book "the Audacity of hope" reflects on the revival of the" American dream", assessing world politics, fights for US hegemony in the international arena [10]. The current American President D. Trump puts forward the idea of leadership lessons that should guide modern politicians and businessmen [13]. Well-known American politicians and political scientists Z. Brzezinski and G. Kissinger write that the new US policy at the present stage have to the transition from global hegemony to global leadership. It undoubtedly has a serious impact on the processes take place in the world $[2,7]$.

The above works provide an opportunity to assess in a new way, taking into account the development of modern civilizations, how our world is developing in the present and what prospects we can expect in the future.

To present some of the modern civilizations problems allowed the research of the French Author F. Braudel. In his book "Grammar of civilizations" he characterizes civilizations as geographical and cultural spaces, and also he attempts to classify civilizations, their role and significance [4]. Among the modern German authors should be called the work of A. Ludtke " The History of everyday life in Germany: New approaches to the study of the work of war and power." The scientist tried to present the story through the eyes of the "little man". He believes that the importance of studying the "history of everyday life" is that the interests of man are ensured by the daily development of the state and society. This unconventional view, in terms of assessing power and society, makes it possible to study the daily lives of people [8]. In the work of German scientist H. Schumacher " Twelve laws of 
power. Secrets of success Angela Merkel " identified 12 positions, which in their activities should be guided by a politician, namely: all the forces to achieve success, winning the party, minimizing risks, build bridges, planned policy $[16,17]$. An interesting work was written by Israeli Researcher Y. N. Harari "21 lessons in the XXI century". The scientist tried to generalize the trends in the development of modern civilizations, and how they affect now and will affect in the foreseeable future, having a serious impact on the world [14].

The famous Russian Scientist N. Berdyaev defined the place and role of Russia in the world community of civilizations as a special civilization, which was called "EastWest" [1]. Russian philosopher I.A. Ilyin, describing modern civilizational processes notes that the West does not know and does not love Russia. He thinks that Russian language, Russian religiosity, Slavic-Russian perception of the world, nature and man are alien to Western Europe [5]. In V. Inozemtsev's monograph "Non-Modern country: Russia in the world of the XXI century" the author characterizes our country as non-modern Russia. Research is highly critical. We cannot agree with the author of this book that Russia has no future. In fact, Russia achieves significant results in the development of the state as a civilization through evolution and reforms, especially in terms of civilizational dialogue with other countries. At the same time, there are still complex problems associated with the need to improve the efficiency of production and specific results of social policy [6].

\section{RESEARCH METHODOLOGY}

The methodology of the research is that by assessing the content of civilizational processes taking place in the world, to show that subjective factors play the same important role as subjective factors that influence the transformation of the international community as a whole; to illustrate how the influence of various actors in the process in the face of economic and political elites seriously affect the options for the development of the world; to consider possible scenarios for the foreseeable future. At the heart of this approach are the interests of man as an integral part of the human community. Research problem:

1. To consider the civilizational processes taking place in the world as a system of modern world and the world order in which different States and communities take part, taking into account their interests and capabilities.

2. To determine the place and role of Russia as a special civilization in the implementation of issues to protect its national interests, its participation in humanitarian activities.

The novelty of the work is that the development of the modern world is shown through a comprehensive analysis of civilizations taking into account the competitive environment in various fields of the international community - economic, social, political and cultural. This approach allows us to use two levels of analysis - paradigmatic and syntagmatic in characterizing trends in the development of modern civilizations. The paradigmatic level enables to compare the development of civilizations between different eras. According to the syntagmatic analysis it is possible to trace how civilizations develop at the same historical time

\section{RESULTS}

The results of this research can be used to clarify the possible policy options of different communities in solving both common global problems and individual specific participants represented by different States. The materials used in the article can be useful at the lessons in such disciplines as History, Economics, Political science, Sociology, Cultural studies, Foreign languages.

Such concepts as globalization or transformation are used in relation to the modern world. Globalization means large-scale profound changes in various spheres of society and the state, which are largely predictable. At the same time, such processes can lead to unpredictable consequences.

One of the most important challenges is technological challenges. Technological challenges have a serious impact on all spheres of society life and the state. Apparently, it is necessary to present possible alternatives to the changes that are happening now and, of course, can occur in the future. One of the main changes that significantly affected us was the Internet. The main organizers and leaders of this phenomenon were constructors and engineers, not politicians, as it was before. Yu. N. Harari writes that the technological challenges of the modern world accompanied by the rapid receipt and processing of information, applying such information to practice. Technological challenges have contributed to the fact that in modern conditions there is an opportunity for different civilizations to use technological innovations. In the Federal Republic, for example, about 40 per cent of the population uses postal voting as a form of voting in elections. In the US 40 per cent of voters in the last presidential election of 2016 voted at gas stations. One of the main postulates of our time says: who owns the information-he owns the future.

In the near future, the economy will be subject to serious changes. The concept of economy means household, home Economics. Economic and social levels of development of the state and society largely depend on how the issues of entrepreneurship will be addressed. economic and social levels of the state and society development largely depend on how the issues of entrepreneurship will be addressed. Modern economic science is characterized with such a new direction as behavioral science. The new behavioral Economics considers the utility of modern economic theory and practical policy. Scientists consider the question of the increasing usefulness of a person whose status needs to be raised all the time. Nobel laureate in Economics R. Thaler writes that an additional hundred thousand dollars in the United States can have a fateful decision for those who are poor. At the same time, he notes that for the rich person the same sum will be insignificant. In this case, Thaler indicates that a person is trying to avoid a situation in which he can suffer losses. Accordingly, a person loves and has to make a profit.

Social policy plays an important role in modern conditions. The stable position of the state and the political elite largely depends on the place and role of the middle class in society. In developed capitalist countries, the middle class accounts for more than $80 \%$ of the working population. In countries with developing economies, this indicator is significantly lower and can be $15-30 \%$.

Perceptions of trends in political processes are changing. If in recent centuries the source of power has moved from gods living in heaven to people living on earth, then soon the process of transferring power may begin from people to technologists, and managers.

There is a serious problem that is associated with the issues of development in modern migration. There is no doubt that issues of migration should be linked with economic and social stability, state capacity of the host those who are 
who is called to become the ruler of the world, the constructor

looking for work and a better life. Such processes have a significant impact on the development of those peoples who receive migrants. For example, the President of France has a well-known expression, according to which due to the sharp increase in the number of migrants in France, France from a state with a French nation turned into a state with a nation of Frenchmen. For comparison, Germany retains such a concept as the German nation.

\section{DISCUSSION}

Today, the attitude of modern man to culture is changing significantly. Modern culture is designed to unite people through interaction and mutual influence of different cultures. The main indicators of a cultural person are extensive knowledge in various fields of science and technology, professional skills in the specialties in which the person specializes. The study and use of foreign languages is of particular importance in modern conditions. received:

During the scientific research the following results were

- challenges can induce civilization to growth and prosperity;

- it is necessary to study the features of formation of its civilization and its place in the development of world civilizations in order to be able to specify the types of civilizations and their problems, to identify perspectives, values of a human community.

\section{CONCLUSIONS}

As a result of the research, the authors of the article came to the following conclusions:

1. Civilizations and civilizational processes are a complex, multifaceted phenomenon inherent in the modern period of development of the world. Civilizational processes were characterized and are characterized with the phenomena of economic, social, political and cultural life. They have a significant impact on world history, world politics, world culture. In our opinion, the most significant result of the development of civilizations is the foreseeable future, in which man can turn from a modern man into a man-God. It is Man of human souls, the humanist in all its manifestations.

2. Such a civilization as Russia should occupy a Special place among other countries and peoples in the future. The civilizational dialogues that our country is called upon to organize are important, and they play a significant and growing role. This should be the civilizational humanistic role of Russia.

\section{References}

[1] Berdyaev N., Russian idea M.: Eksmo; SPb.: Midgard. 2005, 832.

[2] Brzezinski Zbigniew, Brent Scowcroft. Second chance, America and the World (collection: translated from English by O. Kolesnikov, I. Dobrovolsky) - Moscow: AST Publishing house. 2018, 448.

[3] Baudrillard J., Consumer Society. Its myths and structures. M.: Republic; Cultural revolution. 2006, 269.

[4] Braudel, F. Grammar of civilizations / Translated from FR.- M: the Whole world. 2008, 545.

[5] Ilyin I. A. National Russia: our tasks / Ivan Ilyin.The Algorithm. 2018, 464.

[6] Inozemtsev V., Non-Modern country: Russia in the world of the XXI century. Moscow: Alpina Publisher. 2018, 406.

[7] Kissinger, Henry. World order. Moscow: Publishing house AST. 2017, 512.

[8] Ludtke A. History of everyday life in Germany: New approaches to the study of labor, war and power. Moscow: Russian political encyclopedia; German historical Institute in Moscow. 2010, 271.

[9] Berger P., Huntington S. The many faces of globalization. M.: Aspect Press. 2004, 379.

[10] Obama B., the Audacity of hope. Thoughts on reviving the American dream. M.: ABC-classic. 2008, 416.

[11] Putin, V. V. Speech at the Munich conference on security policy on February 10. 2007. URL: // http: www Russian. Seven

[12] Thaler, Richard., New behavioral Economics. Moscow: Publishing House "E". 2017, 368.

[13] Trump Donald. Trump never gives up. Moscow: Publishing House "E". 2017, 240

[14] Harari, Y. N., 21 lessons for the XXI century. Moscow: Sinbad. 2019, 416.

[15] Schroeder G., Solution. My life in politics. Moscow: Publishing House "Europe". 2007, 552.

[16] Alexsandr S. Kuznetsov. Russian Professor's meeting. Russian Journal of Physical Education and Sport. 2019, 14(1), pp. 17-22. DOI: 10.14526/2070-4798-2019-14-1-18-24

[17] Schumacher, H., The twelve laws of Power, Angela Merkel's success secrets. München, Wilhelm Heyne Verlag. 2007, 266. 